\title{
Spheres of communal participation: placing the state within local modes of interaction in rural Uzbekistan
}

\section{Johan Rasanayagam}

'There are no medium sized firms in Uzbekistan, only large and small ones.' (Trader)

The person who said this meant that it is difficult to operate private businesses except on the basis of a single individual or household because of high taxes and levels of regulation, and because of difficulties in obtaining large amounts of long term credit at reasonable rates of interest. Economic activity is seen as divided between the 'state' and 'household' sector. The former is made up of state or privatised former state enterprises subject to varying degrees to central government control, and also joint venture operations with foreign companies, while the household sector consists of individual traders, petty commodity agricultural production on household plots, and small businesses run on the basis of a single individual or household. Broadly adopting this distinction, Ilkhamov (2000) proposes a dual economy in Uzbekistan, made up of a command-type economy geared towards export or import substitution and controlled by central government, and a free market economy based on household production, with each sector operating according to its own logic while at the same time being interconnected. In this article I am interested in how state institutions or the state as an idea encompassing households, state institutions, and the national government administrative hierarchy, can be incorporated within local ideals of active participation in the community and modes of communal interaction, and I argue that in order to do this we have to discard dual economy models which place the state and household into separate spheres.

Mitchell (1998) has argued that the concept of the economy, referring to the structure or totality of relations of production, distribution and consumption of goods and services within a given territory, only emerged in the mid twentieth century. The economy as a reified, self contained entity is an 'effect' created out of the discursive practices which separate it from the state and the household. By placing the economy, state and household into different spheres of action, Marxist writers commenting on agrarian relations in Egypt and Turkey (Stauth 1990, Glavanis \&Glavanis 1983, Aydin 1990) have asked the question of how 'peasant modes of production' have survived within the overall context of capitalist relations in rural areas. Mitchell questions this distinction, arguing that a pre-colonial 'natural' peasant 
economy, isolated from cash crop, commodity production, never existed in Egypt, and that it is impossible to distinguish subsistence and market oriented activity within the household. Sugar cane is cultivated as a cash crop using household labour and cattle raised for sale are bought using rotating credit arrangements with kin and neighbours.

Mitchell recognises that both the economy and the state are structural effects, but while he questions the distinction between the economy-as-effect and the household, he maintains this distinction when it comes to the state-as-effect and the household, or more accurately, the individual. He applies a Foucaudlian approach to argue that the modern individual is constructed as an 'isolated, disciplined, receptive and industrious political subject' within such state institutions as the army, schools, bureaucracy and factories. The state itself comes to be reified by individuals in this process as a structural effect which 'orders, contains and controls them.'

The precise specification of space and function that characterise modern institutions, the coordination of these functions into hierarchical arrangements, the organisation of supervision and surveillance, the marking out of time into schedules and programs, all contribute to constructing a world that appears to consist not of a complex of social practices but of a binary order: on the one hand individuals and their activities, on the other an inert 'structure' that somehow stands apart from individuals, precedes them, and contains and gives a framework to their lives. (Mitchell 1999:89)

Although this approach can provide useful insights, it still maintains the state versus household, public versus private distinction which Mitchell criticises in relation to the economy, and does not allow us to address the question of how actors might incorporate the state within local systems of knowledge and value. To undertake this we need to approach the question at the local level, bottom up rather than top down, and from the viewpoint of households themselves.

This article is based on fieldwork carried out between August 1999 and July 2000 in a village in the Fergana Valley in Uzbekistan. In the first section I critique dual economy models, particularly as they are applied to the Soviet Union, post-Soviet societies and Uzbekistan. In the second section I discuss how the household is constituted in the village in which I conducted research, and identify modes of interaction within it. I deal with this in some detail because it prepares the ground for the final section where I argue that these modes of interaction are extended beyond the household and can, in certain contexts, include state institutions as partners within projects of common interest to all participants. 


\section{Dual economy models}

A dual economy model has often been argued or assumed in accounts of the Soviet Union and the post-Soviet countries. The former is usually described as having had an official and a second or shadow economy, while post-Soviet countries have official and unofficial sectors. A common definition of the Soviet Union's second economy is simply all unrecorded transactions ${ }^{1}$. Alternatively Grossman, employing more ideological criteria, defines the second economy as activity undertaken directly for private gain or which contravened the law (Grossman 1977:25). This definition includes activities which were legally tolerated, such as agricultural production on private plots or teachers offering private lessons, but which were ideologically alien to the Soviet system ${ }^{2}$, as well as illegal activities, ranging from workers using resources from the workplace for private gain (earning levyye dengi or earnings 'on the side'), to 'underground entrepreneurs' who produced on a substantial scale, often operating behind the façade of a state enterprise.

Those who employ a dual economy model, however, usually acknowledge that it impossible to distinguish between legal and illegal activities, as legally rendered services, the private sale of goods produced on household plots, or domestically produced crafts, often involved the use of resources illegally appropriated from the state sector. Moreover, they acknowledge that the official and second economy were interdependent to the extent that one could not exist without the other. Many of the resources employed in private production and exchange were obtained from the state sector. Conversely, enterprise managers relied on informal channels involving personal connections and bribery to gain access to inputs necessary to fulfil state plans, and often employed a person known as a tolkach (pusher) who was adept at gaining resources in this way. Humphrey describes how collective farms in Siberia tried to produce and accumulate 'manipulable resources', by which she means goods produced by the farm but not registered in the official accounts and thus outside the control of state authorities, and also resources over which it had a certain amount of discretion as to its use. These could included land in the form of personal plots and payments in kind which were offered to workers as an added incentive to fulfil state plans. Manipulable resources were used to exchange for defitsitnyye (scarce or shortage) goods needed to fulfil the state plan or sold for cash. They were also used to gain political credit with the local administration by selling the surplus to farms within the raion which had not managed to fulfil their plan, and so ensure that the district plan as a whole was fulfilled (Humphrey 1998:195 onwards). 
Since it is often impossible to distinguish whether a particular transaction was part of the official or shadow economy, these labels can only be notional definitions or 'ideal types' referring to aspects of a single transaction rather than a model suggesting that the economy really was made up of two sectors. If, like Kotkin, we acknowledge that the formal and shadow economies really were one economy with two aspects ${ }^{3}$, then we must discard the dual economy model and find an alternative approach to describe what was going on.

The division of post-socialist economies into formal and informal sectors is similarly problematic. The informal sector is usually defined as economic activity which takes place outside public regulation, a definition which stresses the criminal nature of the informal economy ${ }^{4}$. Johnson, Kaufmann and Shleifer offer a model classifying countries into two distinct groups.

In one, the government offers a sufficiently attractive combination of tax rates, regulations, and public goods that most firms choose to stay in the official sector. In this group, government revenues suffice to provide the public goods, and the unofficial sector is small because the government outcompetes it. In the other group, the government does not offer firms a sufficiently attractive combination of tax rates, regulations, and public goods to keep them operating officially, and hence many of them end up in the large unofficial sector, which offers a more attractive combination. The government budget in these countries does not suffice to offer more public goods, and hence the unofficial sector wins the competition for firms. (Johnson, Kaufmann and Shleifer 1997:169)

Although they allow that a single firm might engage in both official and unofficial activities, they nevertheless present the economy as consisting of two almost hermetically sealed sectors with both sectors being represented in a single firm. Such a firm enjoys public goods such as recourse to the courts to enforce contracts with respect to their legal activities, but must resorts to bribery and private protection or enforcement agencies for their informal transactions. In the context of Uzbekistan, however, legal and illegal transactions are both present in the strategies of businesses, and in household and individual income generating activities, to such an extent that it is not useful to attempt to classify a single transaction as belonging to the formal or informal sector.

The case of Tohirjon is typical and illustrates this clearly. Tohirjon, a school teacher in the village where I conducted my research, receives a salary of 10,000 Sum (US\$15) per month. He has 26 sotok ( 1 sotka, plural: sotok, is equal to 0.01 hectares) of land in the form of 
household plots, most of which he obtained illegally from the kolkhoz, and from which he gains about 19,000 Sum (US\$27) per month in products for sale and household consumption. He buys fertiliser from the manager of the kolkhoz warehouse, who sells it illegally, and hires kolkhoz tractor drivers to till his fields. In addition to this, he teaches private lessons to students preparing to sit the higher education entrance exams, for which he gets about 3000 Sum (US\$5) a month, though this income varies considerably from month to month depending on the number of students he has. He has paid a neighbour in the village who works in the photocopy room of a large foreign joint venture company to make copies of textbooks for use in his preparation courses and for sale to his students, and he was also planning to make and sell cribs or cheat-sheets for students to use in the entrance tests. Although his household plot production, teaching salary and private courses are legal they often depend on illegal transactions to make them possible. The household plot production would not be possible without the illegal sales of land, fertiliser, and tractor services, and the income from the private lessons is tied up with resources illegally appropriated from the joint venture firm. With the exception of the teaching salary, it is impossible to place any particular activity in the formal or informal sector.

If it is not possible to distinguish between an official and an unofficial sector, what of Ilkhamov's distinction between the export or import substituting and the household production sectors. This model is very useful for understanding certain aspects of the relationship between state, kolkhoz and rural households, particularly when viewed from a top down perspective. Despite its formal status as a non-state cooperative with decisions being made by its members, the reality of the decision making process means that the kolkhoz has historically acted as if it were a state institution. During the Soviet period the central government issued production plans which originated in the planning ministries in Moscow and were passed down through the Republican administration in Tashkent and the oblast (regional) level. As far as the main crop, cotton, was concerned, the state was the sole buyer and also the monopoly supplier for most inputs, such as water, power, farm machinery and equipment, and chemical fertiliser.

Since independence the kolkhoz has continued to act as a state institution, despite a number of reforms in the organisation of agricultural production. The government continues to issue procurement plans for cotton and wheat and compulsory quotas for the distribution of sowing land. It remains the monopoly buyer of raw cotton and the monopoly supplier of most nonlabour inputs through state controlled organisations or banks ${ }^{5}$ (Ilkhamov $1998 \& 2000$, World Bank 1999, Khan 1995). Even though, by law, private dehqon farmers (established since 
independence, these are private farmers who are granted from 1 to 10 hectares of land or sometimes more on a rental basis) have the right to make their own planting decisions, they are often forced to grow cotton or wheat as part of the overall plan for the kolkhoz from which their land was granted. Since the state procurement plan for the kolkhoz is not reduced when it grants land to a dehkon farmer, it only grants the land if the farmer agrees to plant crops as part of this plan (TACIS Regional Agricultural Development Project, and my own observation). The real aim of the reforms seems to have been to shift the financial responsibility for agricultural enterprises from the state budget to the enterprises themselves, thus the state can maintain control of the production of strategically important crops, while minimising its financial burden (Ilkhamov 1998:544)

The kolkhoz and the household could be viewed as two separate economies, the former having a strong command economy character, controlled by central government and directed towards the eventual generation of foreign exchange, and the latter geared to household subsistence and petty commodity production for the domestic market and more or less operating on free market principles. In common with other dual economy models, however, this is based on a distinction which cannot be sustained when viewed at the local level. It is not flexible enough to cover state and privatised state enterprises which are not engaged in production for export or import substitution, and also the non-manufacturing state sector such as schools and hospitals. Neither does it take into account production within households of goods for sale abroad and the cross border trading activities. Most importantly, by viewing the kolkhoz and households as separate sectors which interact as if with external entities, this model does not allow us to see how the kolkhoz and other state institutions can be 'localised' within modes of communal interaction. At the local level, as the case of Tohirjon shows, the kolkhoz, school, household plot etc. are all incorporated into his income generating strategies, and distinctions between formal and informal economy, command economy and free market, state and household begin to break down. In order to see how the state can be incorporated within local modes of interaction, we need to view this interaction at the point of local contact, the household and the village.

\section{The household}

It is difficult to make generalisations about what constitutes a household as numerous exceptions can be found to any 'typical' form that is identified. Moreover, as Kandiyoti (1999) has pointed out, residence in one house or compound cannot be used as a definition of a household in rural Uzbekistan because several separate households may constitute a single 
unit of consumption or production or, conversely, a single household may contain more than one independent family. I will begin by outlining the main characteristics of households in the village where I conducted my research and then discuss modes of interaction within it.

Rural households in Uzbekistan have been described as patriarchal and extended with brides (kelin: from the Uzbek verb kelmok: to come) moving to the household of their husband's family (Lobacheva N. 1999, Poliakov S. 1992, Monogarova P. 1969). The married couple are settled either in separate one or two room structures in the courtyard or in a single room in the main house. These extended households usually eat their meals together (living bir qozon: one cooking pot), and pooling the incomes of all individuals into one household budget (bir kassa) which is controlled by the, typically, male head of household.

Residence of married sons with their children within the main parental compound (katta eshik: main door) is a temporary situation. One son, typically the youngest, will continue living in the katta eshik with his family, looking after his parents and inheriting the property on their death. It is the responsibility of the main household to build a separate house for the other sons, though this can take many years, depending on the availability of land from the kolkhoz and other material considerations. Even after a family has settled away from the main household, they may continue to live bir qozon, bir kassa, or both, for some years, with the land belonging to the various households being worked in common and the head of the katta eshik making all major decisions. I shall refer to this type of arrangement as a 'satellite' household, as opposed to an extended household where all the separate families live in one compound.

One principle, which lies at the heart of decisions to live bir qozon or bir kassa, is the responsibility of parents, or the katta eshik, to pay for the life cycle rituals of their children; circumcision feasts for boys, wedding celebrations, and building a house for married sons. I calculated the expenditure on one wedding which was described as above average. The bride's side spent over 950,000 Sum (US\$1350) on the dowry, furniture and the wedding feast while the groom's family spent 685,000 Sum (US\$ 970) on gifts to the kelin's family, clothes for the groom and the wedding feast itself. This represents a very substantial expenditure $^{6}$ and households start collecting items for dowries while their daughters are still young children. People estimated that it cost between US\$500 and US\$1000 to build a decent two room house, the minimum acceptable for a newly established household, while a circumcision toi (feast) could cost about $\$ 200$, the same as the wedding toi but without the substantial gifts to the bride or groom's family and the dowry. Another large expense is obtaining higher education, which can entail large outlays on private courses to pass 
university entrance tests and sometimes bribes as well. A study commissioned by the World Bank (1999) which surveyed people's attitudes to poverty and its causes found that respondents considered it a parent's responsibility to arrange for their children's weddings and provide them with a secure start in life, which means a house, household goods and education beyond secondary school. They included the ability to do this as a criterion in defining whether a person was rich or well to do, and cited as one of the causes of impoverishment the need to meet the costs of weddings. Those who had already taken care of this before the worsening economic situation since independence were considered to be in an advantageous position, they could 'relax'.

While the need to provide for circumcision celebrations, weddings and housing is an important factor in decisions to remain bir kassa or bir qozon, other factors are also important. Levels of poverty have dramatically increased since independence. Not only have formal wages decreased, or ceased all together in the case of kolkhoz workers, but prices of consumer goods have increased so people's buying power is much reduced. In addition, medical care and other services, which were freely provided in the past, must now be paid for. Even though medical care and hospital treatment is officially free of charge, doctors and nurses often demand substantial bribes before treating patients. A number of writers have identified reciprocal exchange through informal networks of kin, neighbours and friends as a strategy for coping with material hardship as well as gaining access to scarce resources ${ }^{7}$. Maintaining a united income with separate households is one of the strategies used by villagers to pool labour and to share costs and risks. Moreover, in a situation where access to credit from banks or other 'formal' institutions is impossible for most people, the joint income from extended or satellite households is an important resource. I came across many cases where one household member started a business, for example a shop or a flour mill, using joint household income to pay for the start up costs.

As Kandiyoti (1999) observes, household composition is a dynamic state, changing with time and circumstances. Three brothers in the village all normally lived completely independently, but while they worked seasonally in Kazakhstan as house builders, their wives and children, who remained in the village, once again became bir qozon with the men's parental compound, which also sold off a bull to pay for the extra expenditure on food. Moreover, the main household sometimes selectively chooses which members to retain tied to the common budget and which to make independent according to need and material constraints. A former truck driver and trader I interviewed reported that after he had moved into a separate house site his parents kept him bir kassa with the main compound for ten 
years, until they had married off and settled all their children, because he made a good income from his official salary and trading activities. At the same time, his elder brother, after living with his family in the main household for 5 years, was immediately made independent when he moved to a separate house because of his low income and large family ${ }^{8}$.

Rather than try to define the boundaries of the household, a more productive approach is to recognise that a household is a dynamic set of relationships rather than a fixed entity, and to identify the value systems or principles which shape these relationships. In the context of village households, the dominant principle is living bir kassa and bir qozon. The household acts as a sort of 'holding company', coordinating the projects of its various members, pooling incomes and providing capital. The actual composition of a household, who is included and the degree to which members live bir kassa and bir qozon, is contingent upon the needs at a particular time, which might include the obligation of the main household to provide for the life cycle rituals of its members, education expenses, the need to raise capital for income generating projects an so on. Alongside this, another principle operates, that each member contributes what they are able to the common budget and is allotted from it what they are judged to need, irrespective of their contribution. The household as a whole is the unit of consumption, income and expenditure and inequalities as to the contributions and benefits of individual members are not considered. Ikramjon, the second oldest son in a household, had apprenticed with a leather tanner and then set up on his own. He manages the business in terms of day to day decisions independently from the rest of the household, through his brothers contribute labour and the business is financially integrated within the household budget. During my fieldwork, he decided he wanted to enter the Law Institute in Tashkent and so increased the scale of his leather tanning operations, taking on more apprentices. He continued to hand over all the profits from this to the household budget controlled by his father and told me that when the time comes his family would give him the money he needs. Any excess cash generated at the present time will probably be used to buy cattle, a savings and investment strategy'. Ikramjon does not consider the household budget as a 'bank' where the money he contributes now can be drawn out at a later time on a directly proportional basis, but he knows that the household wealth has to be built up in order to finance his studies in the future.

In actuality access to resources is often unequal, and Kandiyoti (1999) has pointed out the inferior access of women to money within rural Uzbek households. In my own field work I noticed that men attended community celebrations or special meals with other male friends or colleagues, where the quality of food was much higher than normal meals at home, much 
more frequently than women, a fact men are often not aware of. While inequality of access to resources is an important issue in itself, here I am concerned with how modes of interaction within the household can be extended to wider contexts and identifying basic principles is more important for this than actual inequalities as to how the needs of various household members are assessed.

\section{Spheres of communal participation}

A villager told me that a household was a small mahalla ${ }^{10}$, referring to the fact that his eldest son who lives separately continues to contribute part of his income to the parental household. The villager regarded the mahalla as an arena of communal interaction and cooperation which he could use as an analogy for relations within his own household. The collection of articles edited by Carsten (2000) use the term 'relatedness' to encompass emotional and social ties beyond the bounds conventionally defined in the study of kinship relations. Stafford's contribution is particularly relevant to my topic. He describes the 'cycle of laiwang', the building up of relatedness within a community among people not related by kinship through mutual assistance, reciprocal exchanges of money at wedding ceremonies, through 'small actions and interactions'. He argues that laiwang can be characterised as an extension of the 'cycle of yang', the system of mutual obligations between parents and children within the household, which similarly entails the transfer of money and the sharing of food. In both laiwang and yang, transfers create an obligation on the part of the recipient to return them at a later date, though not necessarily in the same form.

While Stafford's account extends modes of interaction within households to wider contexts, laiwang and yang are based on a form of 'balanced' or 'generalised' reciprocity, to use Sahlins' terms, which are not a suitable idiom for describing the bir qozon, bir kassa relations I have described. Moreover, I argue that 'relatedness' is not necessarily created through exchange, but that belonging to a social unit itself carries with it certain modes of interaction, and that the composition of the social unit is contextually determined by shared interest.

When talking about interaction beyond the household in rural Uzbekistan, it is important to distinguish between contexts where participants contribute and benefit equally, and where contributions and benefits relate to ability and need. An example of the former would be the chyornaya kassa, a form of rotating credit group where members contribute a fixed amount to a common fund at regular intervals and take turns to receive it. The groups I came across in the village all consisted of work colleagues, and the amount to be contributed was usually calculated in terms of kilos of beef in order to compensate for high inflation, though in one 
group the 'target' each month was the amount needed to buy a certain television set. A gathering which shares some of the characteristics of the chyornaya kassa is the gap, though this has a more social basis. A gap is an occasion when a group of work colleagues, relatives, classmates from university or school etc. regularly meet over a meal, taking turns as host or gathering in a restaurant. In some groups, money may be collected from participants and given to the host. This may be just enough to pay for the food or it may provide a little extra for the host, in which case the gap also serves as a form of rotating credit group, and this is particularly true for women's gaps ${ }^{11}$. While capital may be raised in this way, the gap is primarily an occasion of communal consumption and sociability, and as with the chyornaya kassa participants contribute equally.

In contrast to interaction on the basis of strictly equal contributions, in certain contexts participants within a project contribute only according to their means and benefit equally, irrespective of the size of that contribution. The year before I arrived in the village, Kamolaka, the father of the largest private farmer in the village, organised the asphalting of a main road. He had previously tried unsuccessfully to persuade the oqsoqol, mulla and elders of his mahalla to hand over money raised for the renovation of the mosque, but which had not been spent because the mosque was closed by the government authorities in response to Islamic extremist activities ${ }^{12}$. When they refused, he raised money from households along the road (Kamol-aka himself is a member of one of these) and from residents of two other mahallas who also benefited from the access the road provided. Each household contributed what it could afford. Kamol-aka contributed 10,000 Sum, a wealthy pharmacist gave 5000, and typical contributions from other households were 2000 Sum or less. He obtained tractors from the kolkhoz and negotiated with a local factory for materials. While I was conducting my research, he was planning to organise the surfacing of other roads in the mahalla and was again trying to drum up support from residents for using the money raised for the mosque. He had already persuaded the kolkhoz authorities to provide tractors and fuel and pay the drivers' salaries. All participants in the project, including the kolkhoz, contributed according to their means while all benefited equally from the outcome.

Money is not the only medium through which interaction beyond the household takes place on this basis. Hashar, the contribution of labour to community projects or the production efforts of other households without monetary reward, is common and occurs in a variety of contexts. A common occasion is house building. Villagers claim that during the Soviet period the whole mahalla or village would cooperate in building residential houses and this was organised by the oqsoqol of the mahalla where the house was being built. Nowadays only 
people who maintain close social relations to those building the house will contribute labour. Villagers said that people have less time to spare, perhaps because it takes much more time and effort to make a living now than during the Soviet period. Hashar is also used for work on private plots, and again those participating usually have a close social relationship with the plot owner. The 'host' of the hashar will usually provide a meal and if crops are harvested participants may be given a share, though this is not calculated in proportion to the work done. This is true even when the hashar is organised to harvest crops for market sale. While the norm is that participants contribute labour for free, I came across some cases where such labour was paid for, though at rates well below the market rate.

Hashar might seem to belong to a different category from the road building project, in that only one party benefits while others contribute labour. However, this is not simply a system for the reciprocal exchange of labour, 'I will help you with your harvest and you will help me with mine'. The sisters of one man, Muratbey, who had married and moved into their husbands' household, regularly worked on his plots with their children, while their brother did not reciprocate by working on their plots. One sister lived in a town and her household did not have any cultivable land. Moreover, Muratbey's brother's son also worked on his plots while his own children were too young to do the same on his brother's land in return. At other times, however, Muratbey had helped his sisters in a number of ways. He give one of his sisters enough money to organise the paperwork involved in obtaining a new job, and he negotiated for the rental of some land from the kolkhoz on behalf of another, as he was on better terms with the brigadier responsible. Hashar is only one part of a wider relationship based on common interest and mutual aid which encompasses not only kin, but also former classmates, neighbours and others.

It is possible to identify a sphere of interaction, including the household but also extending beyond it in certain contexts, which is marked by principles of communal participation, contribution and benefit. These spheres, which I shall call 'spheres of communal participation', may be fairly constant through time, such as the household, or actualised for a limited period as in the case of a road building project. The participants within the sphere are similarly determined by the nature of the project in question, and the kolkhoz, other state institutions and the state itself can be included in certain contexts. Villagers expressed the view that the kolkhoz was a communal resource, an institution which is morally obligated to look after the general wellbeing of the community rather than be for the benefit of specific individuals. One villager disapproved of private farms because they took land away from the kolkhoz and the general community and placed it under the control of a single household. 
Another asserted that the kolkhoz was only a collective in name, not in reality, since it did not have enough income to supply the needs of the people and could not pay salaries. It was not a real collective because its administration appropriated all the income for themselves. 'We are also part of the kolkhoz', said one teacher when he told me he was using a kolkhoz combine to process wheat grown on his own household plots.

In its past and present activities, the kolkhoz often realised this role. During the Soviet period the kolkhoz provided the village with roads, electricity and gas, and built the schools, while the central government paid teachers' salaries and provided the equipment. People definitely felt that the kolkhoz had provided these things rather than the central government. Now, even though it does not have the resources to provide or maintain the village infrastructure as was its responsibility in Soviet times, it still supports the village as a whole where it can. Land for private plots comes from kolkhoz land and is granted to anyone who is a permanent resident whether they work for the kolkhoz or not, and it also provides the water which irrigates these plots free of charge. In the past the kolkhoz has also given land for the building of communal structures such as mosques and graveyards. I have already described how the kolkhoz participates in community projects such as the asphalting of a dirt road, something it should have been responsible for but lacks the resources to carry out on its own, and the kolkhoz sponsors cultural and sporting events, though on a much reduced scale than in the past. During my fieldwork it contributed to the prize money for a football competition, and organised a concert in the yard of one of the schools.

Social services such as schools and health care facilities can also fall into this sphere. Wealthy individuals often financially support such institutions, much as the kolkhoz did in the past, and when the village school approached parents for a contribution of 100 Sum each to carry out some repairs, a wealthy private cattle farmer and the largest trader in the village each contributed 10,000 Sum. In a similar way, each household contributed to the renovation of a health centre in the village. Private sponsorship of state-provided social services is not confined to the village. In a nearby town I visited a school which was sponsored by the owners of two local factories, one of whom had also renovated another school himself.

The state, as an encompassing idea connecting households with state institutions, such as schools and hospitals, and the hierarchy of government administration, can conceptually be included in the sphere of communal participation, though more as an extension of principle than in practical activity. I was present during a conversation between a knife maker and a teacher at the village school where the knife maker regretted that he had never done any work for 'society' (jamiya uchun), by which he meant working for the kolkhoz, school or other 
state or social institution, but had always worked privately for himself. When later I brought up the subject with the teacher, he said that some people in the village only worked for themselves, they only kept cows, paid no tax to the state and didn't care about the people around them. Keeping livestock is a savings and investment strategy which most people engage in, including the teacher. However, most of the work involved, from growing the maize for fodder to feeding and selling the animals, can be undertaken within the household without recourse to outside help. I think the teacher was using the keeping of livestock as a metaphor for income generating activities which have little benefit for the wider community and entail minimal interaction with it. It is also interesting that both the knife maker and the teacher viewed working in a state institution and paying taxes as contributing to society. In return for taxes the state pays salaries, pensions and other benefits.

A central feature of spheres of communal participation is that the aims of the project around which it is mobilised address the material interests of participants, and the closer these aims are, the greater is the sense of being part of a single consumption, production or expenditure unit. A group of households participating in the building of a road form a much more distinct group in terms of their actual contributions of time, labour and money, than the more generalised sentiments that the kolkhoz ought to function for the good of the whole community, or the even further generalised notion that paying taxes or working in the "social sector' is a way of contributing to the state as imagined as the larger, encompassing community. The kolkhoz or state institutions such as schools and health centres are included within the sphere of participation in a much more concrete manner when they are the object of a project of more immediate benefit to participants, as in cases where parents are asked to contribute to renovation work of a school, or when they are one of the participating agents in a project, for example when the kolkhoz provides tractors and fuel to transport the material to build a road.

At the same time, material interest is not the only thing which unites participants. Spheres of communal participation are actualised within a social context which values active participation within a community. Rassudova (1969) shows how common material interest was combined with membership in a single social unit in the area around Samarkand in the $19^{\text {th }}$ century. She writes that a number of villages watered from a single main canal formed a water managing unit, electing a representative to supervise the watering of fields, the buying and selling of land, cleaning and maintenance of the main canal and crop rotation. Each village contributed labour for any necessary work in proportion to the water it received. The villages making up such a unit were known as qozonsherik (sharing one cooking pot) 
reflecting the fact that they constituted a social unit as well, jointly owning large cooking pots for communal feasts and mutually attending each other's tois. The spatial distribution of cultivated plots reproduced settlement patterns, so residential neighbours would also cultivate neighbouring fields. Each household cultivated their land independently but pooled animal power and labour when necessary with cultivators of neighbouring plots, for example at harvest time or for ploughing. This exchange of labour was also known as hashar, for which no monetary payment was given.

The kolkhoz and other state institutions took over the regulation of the irrigation infrastructure and the distribution of land from the pre-Revolutionary local community organisations, which in the past encompassed all local users within a cooperative productive and social unit. At the same time, however, the ideal of active participation in the community has remained and is actualised in a number of ways. I attended an iftar in the village, the first meal after sunset to break the fast during Ramadan. The host invited the mahalla oqsoqol, the mulla and other older men from the two neighbouring streets and the reason he gave for organising the meal was to show respect to those attending, to repay the times his father (now deceased) had attended similar gatherings in his old age, and because he had not held a toilike celebration for the past five years since his youngest sister's marriage. Households sometimes host feasts for their neighbours in the absence of a recent marriage or circumcision toi as a way of 'paying back' for the celebrations they have attended, and of participating in the social life of the mahalla.

People earn respect in the village through contributing to the community around them. Rich people are expected to contribute more than the less well off, but the fact of the contribution is more important than the actual amount. This contribution does not have to be financial, and is more about fully taking part in community life. The teacher who talked about working for society, said that for him this meant meeting and interacting with colleagues at school and helping his neighbours where he can. He mentioned that he had a neighbour who was too poor to contribute financially to common projects but was always ready with advice, meaning that he was prepared to participate within the community, and was therefore respected. A successful trader was respected because he was always ready to contribute, whereas a private cattle farmer was criticised for only having started involving himself in the community since he went on pilgrimage to Mecca ten years ago, before which he just looked out for himself and his family. When the villagers who just kept cows are criticised, it was not just that they do not pay taxes, but more importantly that they do not care about the people around them, they 'only think about their cows' and do not participate in the social life of the community. 
There is an ideal of active participation within the community, where the level of contribution is less important than the fact of making a contribution, and where each is expected to contribute according to their ability. In order to be realised in action, within spheres of communal participation, a degree of shared material interest is important, and the household is the domain where the sense of shared interest is most completely experienced. While participants in a road building project may constitute a single unit within the limited context of that project, household members are part of a temporally continuous project which encompasses the whole life experiences of its members. Individual state institutions can be incorporated within spheres of communal participation, either as a participant alongside households, as in the case of the kolkhoz within the road building project, or as an object of a project. The state can also be incorporated, if not in practical action, then as the imagined, encompassing community within which individuals and households are expected to actively participate through paying taxes and working in 'social' institutions such as the kolkhoz or the school.

\section{Conclusion}

I recognise that as far as the relationship between households and state institutions are concerned, or how the state is imagined by individuals in rural Uzbekistan, the incorporation of the state within spheres of participation is only part of the story. In other contexts the state may indeed exist as a reified entity external to the individual, as Mitchell argues, and Ilkhamov's distinction between a central government controlled command-type economy and a market oriented household economy is useful for understanding much of the relationship between government authorities, the kolkhoz and rural households. However, the state is imagined by individuals in a multidimensional way, and while it may be imagined and treated as an external entity, perhaps to be resisted or avoided, state institutions can also be incorporated within local systems of value. Dual economy models make a distinction between formal and informal sectors, the public and the private, which draws boundaries around the state, household and economy, and places each in a separate domain. When viewed at the level of local interactions these distinctions break down, and we can see how state institutions can be drawn into local modes of interaction, not as external entities but as participating partners. 
1 'In contrast to the legitimate market/black market model, the Soviet state operated as an economy that commonly had two kinds of transactions within it: the official dealings, announced and recorded, and those of the second economy, which were not. This meant that the second economy was virtually co-extensive with the whole economy, and involved almost the whole population, to at least some extent. In addition, to the legal economy operating by means of controls, plans, directives, quotas and the like, the second economy made quasimarket arrangements available for the whole of society in respect to at least part of the material needs of the people.' (Kurkchiyan 2000:84)

${ }^{2}$ This is also the definition used by Sik (1992) who defines the second economy as activity outside the socialist sector.

3 'The shadow economy was not an independent entity but a corollary to the official economy; it was the shadow economy that permitted the official economy to function, and visa versa. The two economies were mutually dependent and shaded off one into the other; separated, each would have ceased to exist. Put simply, there was really one economy with a dual aspect: some activities were legal, others were not; some illegal activities were condoned, but not all. And the determination more often than not was arbitrary.' (Kotkin 1995:274)

4 'The informal economy has been reduced to activities that cannot be called by any names other than cheating and corruption - activities such as tax evasion, stealing from employers, illegal contracts, bribing politicians and officials, money laundering, and so forth.' (Kurkchiyan 2000:96)

${ }^{5}$ Although the banks granting credit to agricultural enterprises are officially non-state their financing comes from the State Central Bank which controls their operations.

${ }^{6}$ I conducted a survey of incomes of 20 households in the village. This was not a random sample but represented a range of income levels and occupations. In this sample, combined household incomes (including official salaries, pensions and other transfer payments from the state, income from agricultural activity, other businesses and trade) ranged from 18,500 to 119,000 Sum per month.

${ }^{7}$ On the use of networks as a coping strategy in situations of material hardship, Kandiyoti (1998) writes about women's gaps (rotating credit societies) in Uzbekistan, Hoodfar (1997) and Singerman (1995) describe the use of informal networks in Cairo, and Ledeneva (1998) describes blat networks or relations in accessing scarce goods and services in Soviet Russia.

${ }^{8}$ Kandiyoti (1999:504) gives a similar example of a widow living on the low income provided by a pension who decided not to share her cooking pot with her elder son and his family since she could no longer afford to feed them all, but instead remained bir qozon only with her younger disabled son and his family.

${ }^{9}$ Raising cattle for beef is a very popular method of saving. While the price of most agricultural produce fluctuates dramatically from season to season, the price of beef usually rises steadily and keeps pace with inflation.

${ }^{10}$ A mahalla is a territorially based residential and social unit, headed by an oqsoqol chosen by residents. The oqsoqol, mulla, and older, respected residents play an important role in settling disputes within the mahalla, upholding moral and social norms, and supervise and officiate at communal celebrations such as wedding tois. 
The mahalla collectively owns cooking equipment, crockery, tables etc. for use at these celebrations purchased from contributions from residents. See Basilov (1996) for an account of mahallas in a Fergana Valley village.

${ }^{11}$ See Kandiyoti (1998) for an account of women's gaps.

${ }^{12}$ After 1985 and the relaxing of restrictions on religious freedoms mosques in the village were reopened and new ones were built, and mosque attendance increased further after independence. After incidents involving Islamic opposition elements in 1995 in the nearby city of Namangan all the mosques in the village except one were once more closed, or rather, the authorities told people not to attend them although they were not actually boarded up. In the case of the mosque I am writing about, villagers told me that the raion authorities closed the mosque on the pretext that it did not have a proper gas and electricity meter. Money was raised from mahalla residents to remedy this and a delegation was sent to Andijan (the seat of the viloyat (provincial) government) and to the capital Tashkent to petition for the reopening of the mosque but this was refused. It is this money which the father of the cattle farmer wanted to use for the road surfacing project. 